\title{
KARAKTERISASI ASAM LEMAK HASIL HIDROLISIS PADA MINYAK BIJI KELOR (Moringa oleifera) DENGAN METODE KROMATOGRAFI GAS-SPEKTROSKOPI MASSA
}

\author{
Yuszda K.Salimi ${ }^{1 *}$, Netty Ino Ischak ${ }^{2}$,Yusni Ibrahim ${ }^{3}$ \\ ${ }^{1}$ Program Studi Kimia, FMIPA Universitas Negeri Gorontalo \\ ${ }^{2,3}$ Program Studi Pendidikan Kimia, FMIPA Universitas Negeri Gorontalo
}

${ }^{*}$ Corresponding author:

email:

yuszdasalimi23@gmail.com

Received: 18 March, 2019

Accepted: 19 March, 2019

Online : 20 March, 2019
Abstract. This research aims at finding out characterization of a hydrolyzed fatty acid from moringa seeds oil (Moringa oleifera). Samples analyzed are dried and wet seeds which extracted through n-hexane to obtain oil. The extracted oil is analyzed for acid value and saponification value. Then, the hydrolysis of extracted oil with $\mathrm{KOH}$ solution and $\mathrm{H}_{2} \mathrm{SO}_{4}$ catalyst becomes free fatty acids, fatty acids analysis is then converted to be methyl ester using $\mathrm{CH}_{3} \mathrm{OH}$ solvent and $\mathrm{H}_{2} \mathrm{SO}_{4}$ as catalyst. This research uses gas chromatography mass spectrometry analysis, fatty acids of dried moringa seeds were lauric acid, paltoleic acid, palmitic acid, oleic acid, stearic acid, and arachidic acid. Meanwhile, fatty acids of wet moringa seeds were paltoleic acid, palmitic acid, oleic acid, stearic acid, eicosanoid acid, arachidic acid, behenic acid, and lignoceric acid. The highest component of methyl ester on both moringa seeds are methyl oleate with each presentation is $38,08 \%$ and $38,84 \%$

Keywords: Moringa seeds, Fatty acid, GC-MS

Abstrak. Penelitian ini bertujuan untuk mengetahui karakterisasi asam lemak hasil hidrolisis biji kelor (Moringa oleifera) dengan metode kromatografi gas-spektroskopi massa. Sampel yang digunakan dalam penelitian ini adalah biji kelor kering dan basah. Sampel biji kelor diekstraksi menggunakan $n$-heksan untuk memperoleh minyak. Ditentukan bilangan asam dan bilangan penyabunan. Menghidrolisis minyak hasil ekstraksi dengan larutan $\mathrm{KOH}$ dan katalis $\mathrm{H}_{2} \mathrm{SO}_{4}$ menjadi asam lemak bebas, analisis asam lemak kemudian dikonversi menjadi metil ester dengan menggunakan pelarut $\mathrm{CH}_{3} \mathrm{OH}$ dan $\mathrm{H}_{2} \mathrm{SO}_{4}$ sebagai katalis. Penelitian ini menggunakan Kromatografi Gas-Spektroskopi Massa untuk mengidentifikasi asam lemak dalam sampel. Dari analisa Kromatografi Gas-Spektroskopi Massa yang telah dilakukan, asam lemak minyak biji kelor kering yang dihasilkan adalah asam laurat, asam palmitoleat, asam palmitat, asam oleat, asam stearat, dan asam arakidat. Sedangkan untuk asam lemak minyak biji kelor basah yang dihasilkan adalah asam palmitoleat, asam palmitat, asam oleat, asam stearat, asam eikosenat, asam arakidat, asam behenat, dan asam lignoserat. Dimana komponen terbesar metil ester pada biji kelor kering dan biji kelor basah adalah metil oleat dengan persentasi masing-masing $38,08 \%$ dan $38,84 \%$.

Kata Kunci: Biji Kelor, Asam Lemak, KG-SM

\section{PENDAHULUAN}

Minyak merupakan salah satu penyusun utama tubuh hewan dan tumbuhan. Minyak yang berasal dari hewan digolongkan sebagai minyak hewani atau disebut lemak saja, sedangkan minyak dari tumbuhan digolongkan sebagai minyak nabati dan disebut sebagai minyak (Fessenden dan Fessenden, 1986 dalam
Pranowo dan Muchalai, 2004). Minyak dan lemak tidak berbeda dalam bentuk umum trigliseridanya dan hanya berbeda dalam bentuk (wujud), disebut minyak jika berbentuk cair pada suhu kamar dan disebut lemak jika berbentuk padat pada suhu kamar (Ketaren, 1986).

Minyak merupakan ester dari molekul gliserol dan tiga molekul asam lemak, oleh karena 
itu disebut juga triasil gliserol atau trigliserida. Asam lemak yang terkandung dalam trigliserida berpengaruh beasr terhadap sifat minyak dan merupakan penentu sifat fisika dan sifat kimia minyak. Lemak yang mengandung asam lemak dengan titik lebur rendah biasanya berwujud cair pada suhu kamar, dan lemak yang mengandung asam lemak bertitik lebur tinggi cenderung berwujud setengah padat atau padat pada suhu kamar. Asam-asam lemak yang terikat membentuk trigliserida merupakan asam organik berantai lurus yang biasanya merupakan atom karbon antara 16 samapai 24 atom per molekul.

Berdasarkan ada atau tidaknya ikatan rangkap karbon-karbon di dalam asam lemak, dikenal asam lemak tak jenuh dan asam lemak jenuh. Asam lemak tak jenuh adalah asam lemak yang memiliki ikatan rangkap karbon-karbon, sedangkan asam lemak jenuh adalah asam lemak yang tidak mengandung ikatan rangkap pada ikatan antara atom-atom karbon penyusun asam lemak tersebut (Pranowo dan Muchalal, 2004).

Tanaman kelor (Moringa oleifera) merupakan salah satu jenis tanaman tropis yang mudah tumbuh di daerah tropis seperti Indonesia. Kelor dapat tumbuh pada daerah tropis dan subtropis pada semua jenis tanah dan tahan terhadap musim kering dengan toleransi terhadap kekeringan sampai 6 bulan (Aminah, dkk. 2015). Moringa oleifera ditanam terutama sabagai tanaman pagar. Pemanfaatan buah Moringa oleifera di Indonesia belum optimal. Buah Moringa oleifera lazim di gunakan sebagai bahan makanan bagi masyarakat Indonesia khususnya di pulau Jawa dan sebagai bahan koagulan dalam penjernihan air (Nasir, dkk. 2010). Selain itu, bagian dari tanaman ini seperti bunga, daun muda dan polong/biji juga dikenal sebagai tanaman obat tradisional secara turun temurun (Budda et all., dalam Fitriyah, 2013).

Menurut Duke (1983) dalam Widyanastuti (2013) Biji kelor mengandung minyak sebesar 40 $\%$. Minyak kelor mengandung asam lemak sebesar $34.7 \%$. Asam lemak yang terdapat dalam biji kelor yaitu asam palmitat sebanyak 9.3 $\%$, asam stearat sebanyak $7.4 \%$, asam behenat $8.6 \%$, dan asam oleat $65.7 \%$. Selain itu dalam minyak biji kelor juga di temukan miristat dan lignoserat. Komposisi maupun jenis asam lemak dari setiap jenis tumbuhan berbeda. Sampai saat ini informasi tentang kandungan asam lemak yang ada pada biji kelor. Maka perlu adanya penelitian tentang karakterisasi asam lemak hasil hidrolisis pada minyak biji kelor (Moringa oleifera) dengan metode Kromatografi Gas-Spektroskopi Massa.

Tujuan dalam penelitian ini yaitu untuk mengetahui karakterisasi asam lemak hasil hidrolisis pada minyak biji kelor (Moringa oleifera) dengan metode Kromatografi Gas-Spektroskopi Massa.

\section{METODOLOGI PENELITIAN}

\section{Alat}

Peralatan yang di gunakan dalam penelitian ini adalah alat refluks, soxhletas, evaporator dan seperangkat alat kromatografi gas-spektrofotometer massa (KG-SM) Shimadzu tipe QP-2010S.

\section{Bahan}

Bahan utama yang digunakan dalam penelitian ini adalah Biji Kelor. Sedangkan bahanbahan kimia adalah aquadest, n-heksan, methanol, indikator phenoftalein, Asam klorida, kalium hidroksida, $\mathrm{Na}_{2} \mathrm{SO}_{4}, \mathrm{H}_{2} \mathrm{SO}_{4}$ pekat, $\mathrm{NaHCO}_{3}$, indikator universal, $\mathrm{NaCl}$.

\section{Cara Kerja}

\section{Preparasi Sampel}

Penyiapan sampel biji kelor. Biji kelor kering (tua) di kupas kulitnya, kemudian di keringkan di dalam oven pada suhu sekitar \pm 105 ${ }^{\circ} \mathrm{C}$ selama 2 jam. Tujuan pengeringan ini agar kadar air pada biji kelor sudah menguap serta sudah terjadi pengeringan yang sempurna bahkan sudah tidak ada kadar air. Kemudian biji kelor yang sudah kering dihaluskan menggunakan blender. Biji kelor yang sudah dihaluskan kemudian diayak dengan ayakan ukuran 120 mesh. Dilakukan langkah yang sama untuk biji kelor basah (muda).

\section{Ekstraksi Minyak Biji Kelor Kering dan Biji Kelor Basah dengan Metode Soxhletasi}

Biji kelor kering (tua) yang sudah dihaluskan ditimbang sebanyak $150 \mathrm{gr}$ dengan menggunakan neraca analitik. Kemudian dibungkus dengan kertas saring. diperhatikan ukuran bungkusan sampel agar sesuai dengan ukuran soxhlet. Dimasukkan bungkusan sampel ke dalam soxhlet yang telah dirangkai dengan kondensor dan labu didih. Dituang pelarut sebanyak $600 \mathrm{~mL}$ ke dalam labu didih. Kemudian rangkaian Soxhlet tersebut diletakkan diatas pemanas lalu dipanaskan selama \pm 6 jam sehingga didapat hasil ekstraksi berupa 
campuran minyak biji kelor dengan pelarut. Ekstrak n-heksan kemudian dipekatkan dalam rotary evaporator pada temperature $50{ }^{\circ} \mathrm{C}$ sehingga diperoleh minyak biji kelor pekat. Dilakukan langkah yang sama untuk biji kelor basah (muda).

\section{Penentuan Bilangan Asam dan Kadar Asam Lemak Bebas}

Minyak biji kelor sebanyak $5 \mathrm{~mL}$ di masukkan dalam Erlenmeyer $250 \mathrm{~mL}$, kemudian ditambahkan metanol $96 \%$ sebanyak $25 \mathrm{~mL}$ dan dipanaskan pada suhu $60{ }^{\circ} \mathrm{C}$ selama 10 menit sambil di aduk. Setelah itu, campuran tersebut dibagi menjadi tiga bagian dan masing-masing ditambahakan 2 tetes indicator phenoftalein dan di titrasi dengan larutan $\mathrm{KOH} 0,1 \mathrm{~N}$ yang telah di standarisasi hingga berwarna merah jambu. Warna merah jambu ini harus bertahan paling sedikit 15 detik. Volume titran yang dibutuhkan (V $\mathrm{mL}$ ) di catat. Bilangan asam dan kadar asam lemak bebas dalam contoh dihitung menggunakan persamaan 1 dan 2 .

$$
\begin{aligned}
& \text { B.A }=\frac{\mathrm{V} \mathrm{KOH} \times \mathrm{N} \mathrm{KOH} \times \mathrm{Mr} \mathrm{KOH}}{\text { gram sampel }} \\
& \% \mathrm{FFA}=\frac{\mathrm{V} \mathrm{KOH} \times \mathrm{N} \mathrm{KOH} \times \mathrm{Mr} \text { asam lemak }}{\text { berat sampel } \times 1000} \times 100 \%
\end{aligned}
$$

\section{Penentuan Bilangan Penyabunan}

Pertama-tama, ditimbang $\mathrm{KOH}$ dengan kaca arloji sebanyak 0,4203 gr dan dilarutkan dalam $96 \mathrm{~mL}$ metanol. Larutan yang diperoleh dibagi menjadi dua, $48 \mathrm{~mL}$ digunakan sebagai blangko dan $48 \mathrm{~mL}$ lainnya direaksikan dengan 1 gr minyak biji kelor yang akan digunakan sebagai larutan sampel.

\section{Titrasi Larutan Sampel}

Sebanyak 1 gram minyak biji kelor ditimbang dan dimasukkan ke dalam erlenmeyer 250 . Ditambahkan $48 \mathrm{~mL}$ larutan $\mathrm{KOH}$ dalam metanol dan beberapa butir batu didih. Kemudian direfluks selama 30 menit. Setelah itu larutan sampel di bagi menjadi tiga bagian dan di masukkan ke dalam Erlenmeyer yang berbeda serta di tambahkan masing-masing 3 tetes indikator fenolftalein ke dalam larutan tersebut dan dititrasi dengan larutan $\mathrm{HCl} 0.5$ N. Titrasi dihentikan saat indikator berubah menjadi tidak berwarna. Volume $\mathrm{HCl}$ yang dibutuhkan di catat.

2. Titrasi Larutan Blangko

Larutan blangko $48 \mathrm{~mL}$ dimasukkan ke dalam Erlenmeyer. Kemudian direfluks selama 30 menit. Setelah itu larutan dibagi menjadi tiga bagian dan dimasukkan ke dalam erlenmeyer yang berbeda dan masing-masing ditambahkan dengan 3 tetes indikator phenolftalein sehingga larutan blangko tersebut berwarna merah mudah dan dititrasi dengan larutan $\mathrm{HCl} \quad 0,5 \mathrm{~N}$ sampai bening tidak berwarna. Volume $\mathrm{HCl}$ yang dibutuhkan dicatat.

Bilangan Penyabuanan (BP) dapat di hitung dengan menggunakan persamaan 3 .

$\mathrm{BP}=\frac{\left(\mathrm{V}_{\text {blanko }}-\mathrm{V}_{\text {sampel }}\right) \times \mathrm{N}_{\mathrm{HCl}} \times \mathrm{Mr}_{\mathrm{KOH}}}{\text { berat sampel }}$

\section{Hidrolisis Minyak Biji Kelor}

Sebanyak 25 gr minyak biji kelor dimasukkan kedalam labu leher tiga. Kemudian ditambahkan $50 \mathrm{~mL}$ methanol dan $50 \mathrm{~mL}$ larutan $\mathrm{KOH} 12 \%$. Campuran direfluks dengan pengadukan pada temperature $60{ }^{\circ} \mathrm{C}$ selama 90 menit. Hasil refluks dimasukkan ke dalam corong pisah dan ditambahkan dengan $125 \mathrm{~mL}$ aquades serta 31,25 $\mathrm{mL}$ n-heksan. Larutan dikocok dengan kuat dan didiamkan sampai terbentuk dua lapisan yaitu lapisan air dan lapisan organic. Lapisan air dipisahkan dari lapisan organic. Lapisan air ditambahkan dengan asam sulfat $1 \mathrm{M}$ sampai $\mathrm{pH}$ 1. Asam lemak bebas dipisahkan dari lapisan air.

\section{Esterifikasi Asam Lemak Bebas Hasil Hidrolisis Minyak Biji Kelor}

Sebanyak $10 \mathrm{~g}$ asam lemak biji kelor masing-masing dimasukkan kedalam labu leher tiga yang dilengkapi dengan thermometer. Selanjutnya ditambahkan $8,7 \mathrm{~mL}$ methanol dan $0,087 \mathrm{~mL}(87 \mu \mathrm{L}) \quad \mathrm{H}_{2} \mathrm{SO}_{4}$ pekat. Kemudian campuran tersebut direfluks selama 1 jam pada temperatur $50^{\circ} \mathrm{C}$. campuran hasil refluks selanjutnya didinginkan dan dimasukkan dalam corong pisah. Selanjutnya ditambahkna $20 \mathrm{~mL}$ aquades dan dilanjutkan dengan penambahan larutan $\mathrm{NaHCO}_{3}$ tetes demi tetes sambil dikocok dan diukur $\mathrm{pH}$ dengan indikator universal hingga netral. Setelah itu dilakukan salting out dengan menambahkan $5 \mathrm{~mL}$ larutan $\mathrm{NaCl}$ jenuh hingga campuran terpisah sempurna. Larutan dikocok dengan kuat dan didiamkan hingga terbentuk dua lapisan. Lapisan organik ditambahkan magnesium sulfat anhidrat.

\section{Identifikasi Asam Lemak}


Identifikasi asam lemak dilakukan dengan menginjeksikan metil ester dari asam lemak biji kelor pada alat kromatografi gas-spektroskopi massa Shimadzu QP 2010 pada kondisi sebagai berikut:

Temperatur oven kolom $50{ }^{\circ} \mathrm{C}$, temperature injeksi $300{ }^{\circ} \mathrm{C}$, tekanan $13 \mathrm{kPa}$, total aliran 40,8 $\mathrm{mL} / \mathrm{menit}$, laju alir $26,7 \mathrm{~cm} / \mathrm{sec}$, dan aliran kolom $0,54 \mathrm{~mL} /$ menit.

\section{HASIL DAN PEMBAHASAN}

Ekstraksi minyak pada biji kelor kering dan biji kelor basah menggunakan ekstraktor soxhlet dengan menggunakan pelarut n-heksan. Penggunaan $n$-heksan sebagai pelarut disebabkan karena minyak yang akan diekstraksi dari biji kelor kering dan biji kelor basah memiliki sifat nonpolar, sehingga diperlukan pelarut nheksan yang sifatnya nonpolar juga. Proses ekstraksi ini terus menerus berlangsung selama \pm 6 jam. Hasil ekstraksi 150 gram serbuk biji kelor kering didapatkan minyak sebanyak 57,97 gram dengan rendemen minyak biji kelor kering sebesar 38,64\%, sedangkan untuk 150 gram serbuk biji kelor basah didapatkan minyak sebesar 52,21 gram dengan rendemen minyak biji kleor basah sebesar 34,80\%.

Bilangan asam adalah milligram $\mathrm{KOH}$ yang dibutuhkan untuk menetralkan asam-asam lemak bebas dalam satu gram minyak, sedangkan kadar FFA merupakan kandungan asam lemak bebas yang terdapat dalam suatu minyak dimana berat molekul asam lemak tersebut dianggap sebesar asam lemak dominannya dan dinyatakan dalam bentuk persen. Bilangan asam dari minyak biji kelor kering sebesar 10,68 $\mathrm{mg} \mathrm{KOH} / \mathrm{gr}$ dengan kadar asam lemak bebas (FFA) 5,36\%. Sedangkan Bilangan asam dari minyak biji kelor basah sebesar 2,47 mg $\mathrm{KOH} / \mathrm{gr}$ dengan kadar asam lemak bebas (FFA) 1,24\%.

Penentuan bilangan penyabunan ini dilakukan dengan cara titrimetri yaitu dengan cara menitrasi larutan sampel dan larutan blanko, sehingga dapat diketahui bilangan penyabunan dari suatu sampel. Pada saat melakukan suatu pengujian bilangan penyabunan sampel minyak direaksikan dengan $\mathrm{KOH}$ berlebih. Dalam penentuan bilangan penyabunan, asam lemak dan asam lemak bebas dari minyak (sampel) di reaksikan dengan $\mathrm{KOH}$ dalam alkohol dapat membentuk sabun. Semakin besar molekul trigliserida maka semakin banyak juga $\mathrm{KOH}$ yang dibutuhkan untuk menyabunkan sejumlah minyak tersebut. Minyak yang disusun oleh asam lemak berantai C pendek berarti mempunyai berat molekul relatif kecil akan mempunyai angka penyabunan yang besar dan sebaliknya minyak dengan berat molekul besar mempunyai angka penyabunan yang relatif kecil (Hariani dkk., 2013)

Berdasarkan hasil penelitian nilai bilangan penyabunan dari minyak biji kelor kering adalah $15,7108 \mathrm{mg} \mathrm{KOH} / \mathrm{g}$, sedangkan bilangan penyabunan dari minyak biji kelor basah adalah 7,2943 $\mathrm{mg} \mathrm{KOH} / \mathrm{g}$.

Hidrolisis minyak biji kelor kering dan minak biji kelor basah pada penelitian ini berlangsung pada kondisi basa dengan menggunakan basa kuat $\mathrm{KOH}$. Penggunaan basa kuat $\mathrm{KOH}$ ini disebabkan karena air tidak dapat menghidrolisis secara sempurna minyak biji kelor kering dan minyak biji kelor basah, sehingga diperlukan larutan basa untuk menghidrolisis minyak tersebut. Reaksi antara minyak dengan basa dikenal dengan reaksi saponifikasi atau sering disebut reaksi penyabunan. Reaksi penyabunan pada minyak menghasilkan garam asam lemak atau sabun. Selanjutnya garam asam lemak dengan penambahan $\mathrm{H}_{2} \mathrm{O}$ dengan katalis asam $\left(\mathrm{H}_{2} \mathrm{SO}_{4}\right)$ menjadi asam lemak bebas. Massa asam lemak yang diperoleh dari $25 \mathrm{~g}$ minyak biji kelor kering maupun minyak biji kelor basah pada proses hidrolisis adalah 23,68 $\mathrm{g}$.

Esterifikasi adalah tahap konversi asam lemak bebas menjadi ester, dengan mereaksikan asam lemak dengan alkohol. Asam lemak bebas dari minyak biji kelor kering dan minyak biji kelor basah yang diperoleh dari proses hidrolisis ditambahkan dengan methanol $\left(\mathrm{CH}_{3} \mathrm{OH}\right)$ dan asam kuat $\mathrm{H}_{2} \mathrm{SO}_{4}$ sebagai katalis sehingga terbentuk senyawa metil ester. Proses esterifikasi ini dilakukan untuk keperluan analisis kadar asam lemak menggunakan KG-SM. Hal ini dikarenakan asam lemak yang diperoleh dari hidrolisis bersifat nonvolatile (tidak mudah menguap), sementara syarat senyawa yang diperlukan untuk keperluan analisa harus bersifat volatil. Sehingga diperlukan adanya konversi asam lemak bebas menjadi senyawa metil ester. Senyawa metil ester sendiri bersifat volatil (mudah menguap).

\section{Hasil Analisis Menggunakan KG-SM}

Hasil Pemeriksaan (analisis) dengan kromatografi gas untuk metil ester dari asam lemak hasil hidrolisis (minyak biji kelor kering) menghasilkan kromatogram dengan 7 puncak (peak) asam lemak seperti pada gambar 1 dan disajikan pada tabel 1 .

Dari tabel 1 menunjukkan bahwa minyak biji kelor kering terdiri dari beberapa asam lemak 
yang ditunjukkan adanya 7 puncak pada kromatogram KG. Puncak keempat dengan waktu retensi 27,285 memiliki luas area $1,07 \%$ diduga merupakan Asam laurat karena memiliki spektra massa yang sesuai dengan spektra massa asam

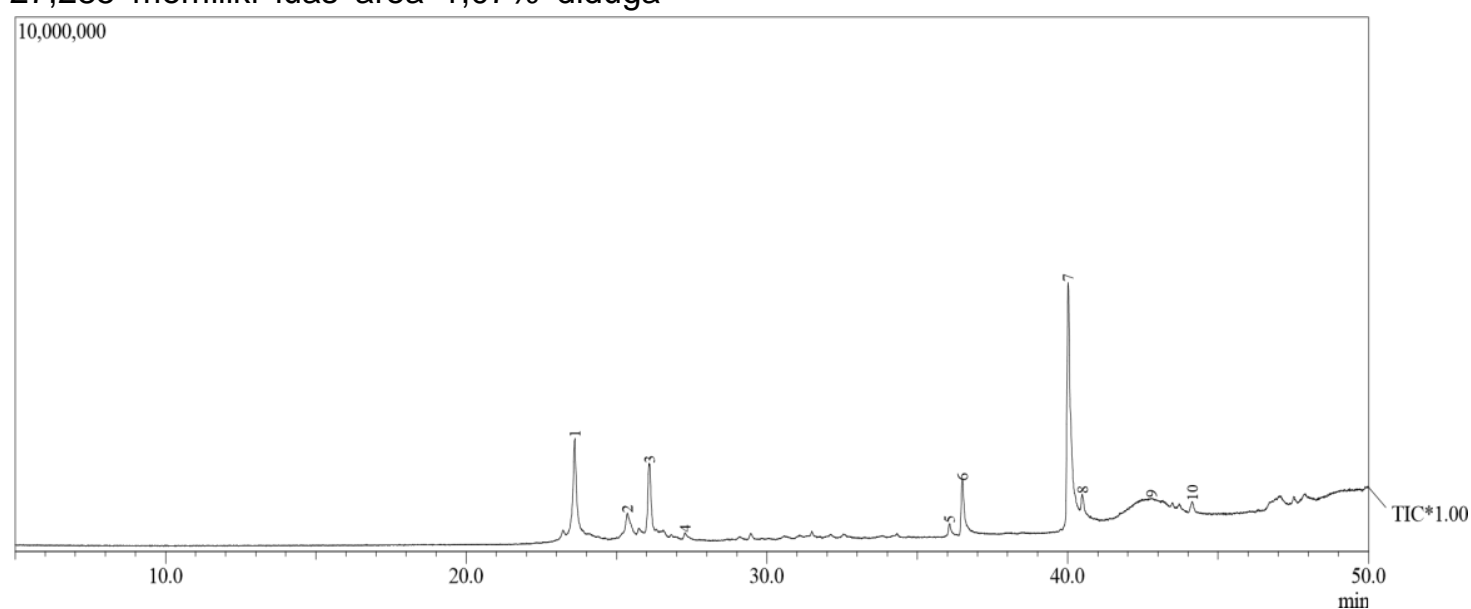

Gambar 1. Kromatogram (KG) Sampel Metil ester (Minyak Biji Kelor Kering)

yang sesuai dengan spektra massa asam dodekanoat (metil laurat) dari WILEY229.LIB dengan nomor entri 79499 dan tingkat kemiripan $92 \%$. Puncak kelima dengan waktu retensi 36,078 memiliki luas area $1,79 \%$ diduga merupakan Asam palmitoleat karena memiliki spektra massa yang sesuai dengan spektra massa asam 9oktadekanoat (metil palmitoleat) dari WILEY229.LIB dengan nomor entri 123056 dan tingkat kemiripan $91 \%$.

Puncak keenam dengan waktu retensi 36,506 memiliki luas area $8,52 \%$ diduga merupakan Asam palmitat karena memiliki spektra massa yang sesuai dengan spektra massa Metil heksadekanoat (metil palmitat) dari

WILEY229.LIB dengan nomor entri 124633 dan tingkat kemiripan 94\%. Senyawa dengan puncak paling tinggi (puncak ketujuh) dengan waktu retensi 40,026 memiliki luas area $38,08 \%$ diduga merupakan Asam oleat. Spektra massa komponen utama metil ester asam lemak hasil hidrolisis $\left(t_{R}=40,026\right)$ menghasilkan puncak ion fragmen pada $\mathrm{m} / \mathrm{z}$ : 41, 55, 69, 74, 97, 98, 123, 137, 152, 166, 180, 207, 222, 235, 246, 264, 266, dan 296. Fragmen dengan $\mathrm{m} / \mathrm{z} 296$ merupakan ion molekul metil oleat yang memiliki rumus molekul $\mathrm{CH}_{3}\left(\mathrm{CH}_{2}\right)_{7} \mathrm{CH}=\mathrm{CH}\left(\mathrm{CH}_{2}\right)_{7} \mathrm{CO}_{2} \mathrm{H}$. Spektra massa puncak ketujuh memiliki kemiripan dengan spektra massa Asam 9-oktadekanoat (metil oleat) dari WILEY229.LIB dengan nomor entri 142893 dan tingkat kemiripan $94 \%$.

Kedua spektra memiliki kesamaan pada ion fragmen pada $\mathrm{m} / \mathrm{z}: 41,55,69,74,96,123$, 137, 166, 180, 222, 264, dan memiliki base peak pada m/z: 55. Puncak kedelapan dengan waktu retensi 40,495 memiliki luas area 1,84\% diduga merupakan Asam stearat karena memiliki spektra massa yang sesuai dengan spektra massa Asam oktadekanoat (metil stearat) dari WILEY229.LIB dengan nomor entri 144208 dan tingkat kemiripan $92 \%$

Tabel 1 Hasil Analisis GC-MS (Minyak Biji Kelor Kering)

\begin{tabular}{|c|c|c|c|c|}
\hline Peak & tR (Menit) & Area (\%) & $\begin{array}{l}\text { BM/Rumus } \\
\text { Molekul }\end{array}$ & Nama Senyawa \\
\hline 1 & 23,615 & 15,85 & $204 / \mathrm{C}_{15} \mathrm{H}_{24}$ & Beta-Patchoulen \\
\hline 2 & 25,369 & 5,27 & $204 / \mathrm{C}_{15} \mathrm{H}_{24}$ & Naftalen \\
\hline 3 & 26,097 & 9,93 & $204 / \mathrm{C}_{15} \mathrm{H}_{24}$ & 1,2,4-Methenoazulen \\
\hline 4 & 27,285 & 1,07 & $214 / \mathrm{C}_{13} \mathrm{H}_{26} \mathrm{O}_{2}$ & Asam dodekanoat/Metil laurat \\
\hline 5 & 36,078 & 1,79 & $268 / \mathrm{C}_{17} \mathrm{H}_{32} \mathrm{O}_{2}$ & $\begin{array}{c}\text { Asam 9-heksadekanoat/Metil } \\
\text { palmitoleat }\end{array}$ \\
\hline 6 & 36,506 & 8,52 & $270 / \mathrm{C}_{17} \mathrm{H}_{34} \mathrm{O}_{2}$ & $\begin{array}{l}\text { Metil heksadekanoat/Metil } \\
\text { palmitat }\end{array}$ \\
\hline 7 & 40,026 & 38,08 & $296 / \mathrm{C}_{19} \mathrm{H}_{36} \mathrm{O}_{2}$ & $\begin{array}{c}\text { Asam 9-oktadekanoat /Metil } \\
\text { oleat }\end{array}$ \\
\hline 8 & 40,495 & 1,84 & $298 / \mathrm{C}_{19} \mathrm{H}_{38} \mathrm{O}_{2}$ & $\begin{array}{c}\text { Asam oktadekanoat/Metil } \\
\text { stearat }\end{array}$ \\
\hline 9 & 42,799 & 16,13 & $284 / \mathrm{C}_{18} \mathrm{H}_{36} \mathrm{O}_{2}$ & $\begin{array}{c}\text { Asam oktadekanoat/Asam } \\
\text { stearat }\end{array}$ \\
\hline 10 & 44,147 & 1,51 & $326 / \mathrm{C}_{21} \mathrm{H}_{42} \mathrm{O}_{2}$ & $\begin{array}{l}\text { Asam eikosanoat/Metil } \\
\text { arakidat }\end{array}$ \\
\hline
\end{tabular}

Yuszda K. Salimi et al. 
Puncak kesembilan dengan waktu retensi 42,799 memiliki luas area $16,13 \%$ diduga merupakan Asam stearat karena memiliki spektra massa yang sesuai dengan spektra massa Asam oktadekanoat (asam stearat) dari WILEY229.LIB dengan nomor entri 134626 dan tingkat kemiripan $83 \%$. Puncak kesepuluh dengan waktu retensi 44,147 memiliki luas area $1,51 \%$ diduga merupakan Asam eikosanoat karena memiliki spektra massa yang sesuai dengan spektra massa Asam eikosanoat (metil arakidat) dari WILEY229.LIB dengan nomor entri 161700 dan tingkat kemiripan $84 \%$.

Berdasarkan data-data tersebut disimpulkan bahwa asam lemak minyak biji kelor kering adalah asam laurat, asam palmitoleat, asam palmitat, asam oleat, asam stearate, asam arakidat. Dimana kandungan asam lemak paling besar minyak biji kelor kering adalah asam 9oktadekanoat atau asam oleat sebesar $38,08 \%$. Hasil ini sesuai dengan penelitian Duke (1983) dalam Widyanastuti (2013) yang menyatakan asam lemak paling besar adalah asam oleat. Hasil ini juga sesuai dengan penelitian Gustone dan Harwood dalam Nasir (2010) yang menyatakan asam lemak paling besar adalah asam oleat.

\section{Data Kromatogram dan Spektrum KG-SM untuk Biji Kelor Basah}

Hasil Pemeriksaan (analisis) dengan kromatografi gas untuk metil ester dari asam lemak hasil hidrolisis (minyak biji kelor basah) menghasilkan kromatogram dengan 9 puncak (peak) asam lemak seperti pada gambar 2 .

Hasil yang dicantumkan pada table 2 menunjukan bahwa minyak biji kelor basah terdiri dari beberapa asam lemak yang ditunjukkan adanya 9 puncak pada kromatogram KG. Puncak pertama dengan waktu retensi 35,971 memiliki luas area $0,90 \%$ diduga merupakan asam palmitoleat karena memilki spektra massa yang sesuai dengan spektra massa asam 9heksadekanoat (metil palmitoleat) dari WILEY229.LIB dengan nomor entri 123056 dan tingkat kemiripan 93\%. Puncak kedua dengan waktu retensi 36,423 memilki luas area 5,15\% diduga merupakan asam palmitat karena memiliki spektra massa yang sesuai dengan spektra massa metil heksadekanoat (metil palmitat) dari WILEY229.LIB dengan nomor entri 124618 dan tingkat kemiripan $94 \%$. Senyawa dengan puncak paling tinggi (Puncak ketiga) dengan waktu retensi 40,071 memilki luas area $38,84 \%$ diduga merupakan asam oleat. Spektra massa komponen utama metil ester asam lemak hasil hidrolisis $\left(t_{R}=40,071\right)$ menghasilkan puncak ion fragmen pada $\mathrm{m} / \mathrm{z}: 41,55,69,74,97,110,123$, 137, 166, 180, 194, 207, 222, 235, 246, 264, 266, dan 296. Fragmen dengan $\mathrm{m} / \mathrm{z} 296$ merupakan ion molekul metil oleat yang memiliki rumus molekul $\mathrm{CH}_{3}\left(\mathrm{CH}_{2}\right)_{7} \mathrm{CH}=\mathrm{CH}\left(\mathrm{CH}_{2}\right)_{7} \mathrm{CO}_{2} \mathrm{H}$. Spektra massa puncak ketiga memiliki kemiripan dengan spektra massa asam 9-oktadekanoat (metil oleat) dari WILEY229.LIB dengan nomor entri 142893 dan tingkat kemiripan 94\%. Kedua spektra memiliki kesamaan pada ion fragmen pada $\mathrm{m} / \mathrm{z}$ : $41,55,69,74,96,123,137,166,180,222,264$, dan memiliki base peak pada m/z: 55 .

Puncak keempat dengan waktu retensi 40,420 memiliki luas area $3,83 \%$ diduga merupakan asam stearat karena memilki spektra massa yang sesuai dengan spektra massa asam oktadekanoat (metil stearat) dari WILEY229.LIB dengan nomor entri 144201 dan tingkat kemiripan $95 \%$. Puncak kelima dengan waktu retensi 41,600 memilki luas area $43,54 \%$ diduga merupakan asam oleat karena memiliki spektra massa yang sesuai dengan spektra massa asam 9oktadekanoat (asam oleat) dari WILEY229.LIB dengan nomor entri 133168 dan tingkat kemiripan $94 \%$. Puncak keenam dengan waktu retensi 43,642 memilki luas area $2,91 \%$ diduga merupakan asam eikosenat karena memiliki spektra massa yang sesuai dengan spektra massa asam 11-eikosenoat (asam eikosenat) dari WILEY229.LIB dengan nomor entri 160588 dan tingkat kemiripan 94\%. Puncak ketujuh dengan waktu retensi 44,077 memilki luas area 2,17\% diduga merupakan asam arakidat karena memiliki spektra massa yang sesuai dengan spektra massa asam eikosanoat (asam arakidat) dari WILEY229.LIB dengan nomor entri 161703 dan tingkat kemiripan $95 \%$. Puncak kedelapan dengan waktu retensi 47,439 memilki luas area 2,14\% diduga merupakan asam behenat karena memiliki spektra massa yang sesuai dengan spektra massa asam dokosanoat (asam behenat) dari WILEY229.LIB dengan nomor entri 176083 dan tingkat kemiripan 95\%. Puncak kesembilan dengan waktu retensi 50,544 memilki luas area $0,51 \%$ diduga merupakan asam lignoserat karena memiliki spektra massa yang sesuai dengan spektra massa asam tetrakosanoat (asam lignoserat) dari WILEY229.LIB dengan nomor entri 187519 dan tingkat kemiripan 93\%. 


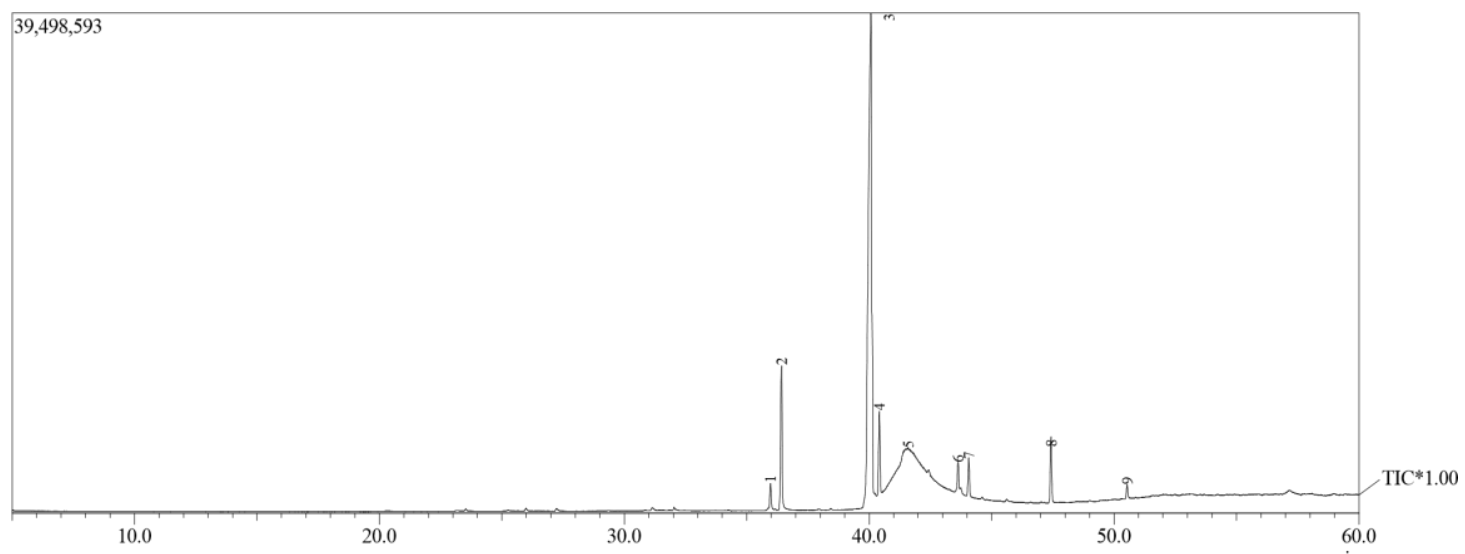

Gambar 2. Kromatogram (KG) Sampel Metil ester (Minyak Biji Kelor Basah

Berdasarkan data-data tersebut disimpulkan bahwa asam lemak minyak biji kelor basah adalah asam palmitoleat, asam palmitat, asam oleat, asam stearat, asam eikosenat, asam arakidat, asam behenat, asam lignoserat. Dimana kandungan asam lemak paling besar minyak biji kelor basah adalah asam 9-oktadekanoat atau asam oleat sebesar 38,84\%. Hasil ini sesuai dengan penelitian Duke (1983) dalam Widyanastuti (2013) yang menyatakan asam lemak paling besar adalah asam oleat. Hasil ini juga sesuai dengan penelitian Gustone danHarwood dalam Nasir (2010) yang menyatakan asam lemak paling besar adalah asam oleat.

Dari data Kromatografi gas dapat disimpulkan bahwa metil ester dari asam lemak hasil hidrolisis minyak biji kelor kering menghasilkan kromatogram dengan 7 puncak (peak) asam lemak sedangkan untuk minyak biji kelor basah menghasilkan kromatogram dengan 9 puncak (peak) asam lemak. Hal ini disebabkan bahwa ada kemungkinan adanya benda asing atau biji yang berkualitas jelek yang tercampur dalam bahan baku serta perlakuan terhadap bahan baku pada saat proses.

Tabel 2 Hasil Analisis GC-MS (Minyak Biji Kelor Basah)

\begin{tabular}{|c|c|c|c|c|}
\hline Peak & tR (Menit) & Area (\%) & $\begin{array}{l}\text { BM/Rumus } \\
\text { Molekul }\end{array}$ & Nama Senyawa \\
\hline 1 & 35,971 & 0,90 & $268 / \mathrm{C}_{17} \mathrm{H}_{32} \mathrm{O}_{2}$ & $\begin{array}{l}\text { Asam 9-heksadekanoat/Metil } \\
\text { palmitoleat }\end{array}$ \\
\hline 2 & 36,423 & 5,15 & $270 / \mathrm{C}_{17} \mathrm{H}_{34} \mathrm{O}_{2}$ & $\begin{array}{c}\text { Metil heksadekanoat/Metil } \\
\text { palmitat }\end{array}$ \\
\hline 3 & 40,071 & 38,84 & $296 / \mathrm{C}_{19} \mathrm{H}_{36} \mathrm{O}_{2}$ & $\begin{array}{c}\text { Asam 9-oktadekanoat /Metil } \\
\text { oleat }\end{array}$ \\
\hline 4 & 40,420 & 3,83 & $298 / \mathrm{C}_{19} \mathrm{H}_{38} \mathrm{O}_{2}$ & $\begin{array}{c}\text { Asam oktadekanoat/Metil } \\
\text { stearat }\end{array}$ \\
\hline 5 & 41,600 & 43,54 & $282 / \mathrm{C}_{18} \mathrm{H}_{34} \mathrm{O}_{2}$ & $\begin{array}{c}\text { Asam 9-oktadekanoat/Asam } \\
\text { oleat }\end{array}$ \\
\hline 6 & 43,642 & 2,91 & $324 / \mathrm{C}_{21} \mathrm{H}_{40} \mathrm{O}_{2}$ & $\begin{array}{c}\text { Asam 11-eikosenoat/Asam } \\
\text { eikosenat }\end{array}$ \\
\hline 7 & 44,077 & 2,17 & $326 / \mathrm{C}_{21} \mathrm{H}_{42} \mathrm{O}_{2}$ & $\begin{array}{c}\text { Asam eikosanoat/Asam } \\
\text { arakidat }\end{array}$ \\
\hline 8 & 47,439 & 2,14 & $354 / \mathrm{C}_{23} \mathrm{H}_{46} \mathrm{O}_{2}$ & $\begin{array}{c}\text { Asam dokosanoat/Metil } \\
\text { behenat }\end{array}$ \\
\hline 9 & 50,544 & 0,51 & $382 / \mathrm{C}_{25} \mathrm{H}_{50} \mathrm{O}_{2}$ & $\begin{array}{l}\text { Asam tetrakosanoat/Metil } \\
\text { lignoserat }\end{array}$ \\
\hline
\end{tabular}

\section{KESIMPULAN}

Dari hasil penelitian yang dilakukan, dapat disimpulkan bahwa: (1) Hasil analisis dengan Kromatografi gas-spektroskopi massa senyawa yang dihasilkan dari minyak biji kelor kering antara lain asam laurat, asam palmitoleat, asam palmitat, asam oleat, asam stearate, dan asam arakidat. Dan kandungan terbesarnya adalah asam oleat dengan kandungan senyawa sebesar 38,08\%. Sedangkan, (2) Hasil analisis dengan Kromatografi gas-spektroskopi massa senyawa yang dihasilkan dari minyak biji kelor basah antara lain asam palmitoleat, asam palmitat, asam oleat, asam stearate, asam eikosenat, asam arakidat, asam behenat, dan asam lignoserat. Dan kandungan terbesarnya adalah asam oleat dengan kandungan senyawa sebesar $38,84 \%$. 


\section{DAFTAR PUSTAKA}

Aminah, Syarifah, Ramdhan, Tezar, dan Yanis, Muhlihani. 2015. Kandugan Nutrisi dan Sifat Fungsional Tanaman Kelor (Moringa oleifera). Balai Pengkajian Teknologi Pertanian Jakarta

Fessenden dan Fessenden. 1982. Kimia Organik Edisi Ketiga Jilid 2. Jakarta: Erlangga

Fitriyah, Nurul. 2013. Analisis $\alpha$-Tokoferol (Vitamin E) pada minyak biji kelor (Moringa oleifera Lam.) secara Kromatografi cair kinerja tinggi. Jakarta: Fakultas Kedokteran dan IImu Kesehatan Program Studi Farmasi

Gritter, R. J., J. M. Bobbit, and A. E. Schwarting., 1991.Pengantar Kromatografi, edisi ke-2, terjemahan Kosasih Padmawinata. Bandung: Penerbit ITB

Harbone, 1987. Metode ekstraksi. Makasar: Universitas Muslim Indonesia. PDF

Hariani, Poedji Loekitowati., Riyanti, Fahma., Riska, Mutia., 2013. Pengaruh Variasi Temperatur Dan Konsentrasi MinyakTerhadap Rendemen Dan Karakteristik Biodiesel Dari MinyakBiji Kemiri (Aleurites Moluccana. Prosiding Semirata FMIPA Universitas Lampung

Herlina, MT., Netti, dan Ginting, ST., M. Hendra S. 2002. Lemak dan Minyak. Fakultas Teknik Jurusan Teknik Kimia Universitas Sumatera Utara. PDF

Hikmah, Nurul Maharani dan Zuliyana. 2010. Pembuatan Metil Ester (Bidiesel) dari Minyak Dedak dan Metanol dengan Proses Esterifikasi dan Transesterifikasi. Jurusan Teknik Kimia, Fakultas Teknik, Universitas Diponegoro. PDF

Insani, Dian Nur. 2012. Studi Esterifikasi Antara Asam Lemak Hasil Hidrolisis Minyak Kelapa Sawit dengan Sukrosa Menggunakan Lipase Candida rugosa EC 3.1.1.3 terimobilisasi pada Matriks Silika $\mathrm{Gel}$ 60. Fakultas Matematika dan IImu Pengetahuan Alam, Program studi Kimia, Depok. PDF

Ketaren, S. 1986. Pengantar Teknologi Minyak dan Lemak. edisi I, Penerbit Universitas Indonesia. Jakarta

Kilo, kadir ahmad. 2012. Analisis Kadar Asam Linoleat dan Asam Linolenat pada Tahu dan Tempe Yang Dijual Di Pasar Telaga
Secara GC-MS. Jurusan Pendidikan

Kimia, Fakultas Matematika dan IPA, Universitas Negeri Gorontalo

Megawati, Rizky Farah. 2010. Analisis Mutu Minyak Atsiri Bunga Cengkeh (Syzygium aromaticum (L.) Meer. \& Perry) Dari Maluku, Sumatera, Sulawesi dan Jawa dengan Metode Metabolomic Berbasis GC-MS. Surakarta: Fakultas Farmasi Universitas Muhammadiyah Surakarta. PDF

Nasir, Subriyer, Soraya, Delfi Fatina, dan Pratiwi, Dewi. 2010. Pemanfaatan ekstrak biji kelor (Moringa oleifera) untuk pembuatan Bahan Bakar Nabati. Jurusan Teknik Kimia Fakultas Teknik Universitas Sriwijaya. PDF

Nurhasanah, 2003. Hidrolisis dan Rekonstruksi Trigliserida. Bogor: Institut Pertanian Bogor. PDF

Poedjiadi, Anna. 1994. Dasar-dasar Biokimia. Jakarta: Universitas Indonesia Press.

Pradana, Rizky Cahya, Soetjipto, Hartati, dan Kristijanto, A. Ign. 2014. Karakterisasi dan Komposisi Kimia Minyak Biji Petai Cina. Program studi kimia fakultas sains dan matematika Universitas Kristen Satya Wacana, PDF

Pranowo, Deni, dan M. Muchalal. 2004. Analisis Kandungan Asam Lemak pada Minyak Kedelai dengan Kromatografi GasSpektroskopi Massa. Jurusan Kimia Fakultas MIPA Universitas Gadjah Mada, Yogyakarta. PDF

Rawai, Novis. 2008 . Bab II Tinjauan Pustaka. (http://digilib.itb.ac.id/files/disk1 /626/jbptitbpp-gdl-novisrawai-31252-32008ts-2.pdf). [Diakses Tanggal 17 Februari 2016]

Sartika, Ratu Ayu Dewi. 2008. Pengaruh Asam Lemak Jenuh, Tidak Jenuh dan Asam Lemak Trans Terhadap Kesehatan. Jurnal Kesehatan Masyarakat. PDF

Sinulingga, Bagus. 2011. Isolasi dan Analisis Komponen Kimia Minyak Atsiri dari Daun Jinten (Coleus aromatikus Benth) dengan GC-MS dan Uji Anti Bakteri. Tesis.Medan : Uneversitas Sumatera Utara.

Sukmajaya, A.P.T.IG.P, Puspawati, N.M, dan Putra, Bawa A.A. 2012. Analisis Kandungan Minyak Atsiri Daun Tenggulun (Protium javanicum BURM.F.) dengan Metode Kromatografi Gas- 
Spektroskopi Massa. Jurusan Kimia Universitas Udaya, Bukit Jimbaran. PDF

Syukri S. 1999. Kimia Dasar 1. Bandung: ITB

Widyanastuti, Nurul Azizah, dan Susilo, Bambang. 2013. Studi ekstraksi Hydraulic Press Minyak Biji kelor (Moringa oleifera) dengan Variasi Perlakuan Panas. Jurusan Teknik Pertanian, Fakultas Teknologi Pertanian, UB Malang. PDF

Yazid, E., 2005. Kimia Fisika Paramedis. Yogyakarta : Andi-Offset 